\title{
HYPOTHESIZED MECHANISM FOR THE INITIATION OF SOIL CAVITIES AND SUBSEQUENT COVER-COLLAPSE IN KARST TERRAIN
}

\author{
James C. Currens
}

\begin{abstract}
Cover collapse is the unpredictable collapse of unconsolidated earth material over soluble bedrock. In Kentucky, cover collapse costs an estimated $\$ 20$ to $\$ 60$ million annually. The Kentucky Geological Survey began keeping a catalog of case histories in 1997 and now receives about 24 reports a year. A total 354 cover-collapse sites were evaluated for this paper, which reports on efforts to discover a relationship between what can be seen (or other otherwise measured) of cover-collapse at the surface and what is happening in the subsurface. The evaluation of measurements made of the cover collapses found $45 \%$ are underlain by Ordovician age carbonates, $41 \%$ are on Mississippian rocks, and $13 \%$ are underlain by Silurian-Devonian stratigraphy. Diameter, elongation (asymmetry ratio), and Riley Sphericity (circularity) were calculated from the length and width of the collapse opening. Distribution of the data is log normal. The diameter of the collapses average $2.4 \mathrm{~m}$. Student's T-tests resulted in a significant difference in depth between collapses underlain by Mississippian versus Silurian-Devonian carbonates. Collapses on Mississippian rocks have large differences in the variance for asymmetry, circularity, and diameter when compared to the variance for Ordovician and Silurian-Devonian cover-collapses. Only $7 \%$ of the cover-collapse sites occur within larger, pre-existing sinkholes. During evaluation of these correlations, it was observed that the cumulative count of cover-collapse per calendar month follows an annual cycle. Collapses are at a minimum in February, but increase to a maximum in July. The count begins to decrease in August and continues to decline through December into January. It is suggested that the air temperature is an important component of the cover-collapse process, possibly accelerating drying of the soil cover, resulting in subsequent collapse.
\end{abstract}

\section{Introduction}

The Kentucky Geological Survey (KGS) has been accumulating data on the timing and location of cover collapse sinkholes since 1997 (Currens, 2012). The original purpose of this investigation was to document these features and identify any trend in the accumulated data that correlated with an above-ground, more easily observed, parameter. This paper reports on efforts to discover a relationship between what can be seen (or otherwise measured) of cover-collapse at the surface and what is happening in the subsurface. For a less technical reference and additional detail on karst in Kentucky see Currens, 2002.

An assemblage of a large data set, to which the analytical methods could be applied, took 19 years. The data collection was limited in scope to sinkholes in Kentucky. Approximately half of the recent sites documented in the field for this paper were documented by the land owner via an online form. The additional information gathered from the owner is important and is notably valuable when digital photographs are included. Although the data set is the largest of its kind in Kentucky and now contains over 354 reports on file as of September, 2015, it is thought to represent only a fraction of the collapse events that have occurred since the KGS began keeping records.

Cover-collapse damage is distributed widely across Kentucky and frequently damaged buildings, roads, utility lines, and farm equipment (Fig. 1). It has killed livestock, including some thoroughbred horses, and has injured people. In Kentucky, cover collapse costs an estimated $\$ 20$ to $\$ 60$ million annually (Dinger, Zourarakis, and Currens, 2007). Of the nearly 4 million people that live in Kentucky, 2.94 million people or 67\% lived on karst in 2010 (Cecil, 2015, Department of Environmental and Earth Sciences, University of Kentucky). One of the more expensive collapse events was the Corvette Museum in February 12, 2004, which cost $\$ 3.2$ million to repair and the damage to the automobiles was an additional $\$ 3.1$ million (Kambesis et al, 2003).

\section{Geologic Setting}

Kentucky karst is developed on extensive outcrops of carbonate bedrock representing vast ranges in geologic age, distinct mineralogy and characteristic primary sedimentary structures. Of a total of 354 cover collapse sites, $41 \%$ are underlain by Mississippian age (Lower Carboniferous) carbonates, whereas $45 \%$ and $13 \%$, respectively, are underlain by Ordovician and Silurian-Devonian rocks. The geology of $1 \%$ of the sites is undetermined. The sites are located on 32 different, formal stratigraphic units and the distribution parallels the exposed carbonate area of each geologic system (Fig. 1).

University of Kentucky, Kentucky Geological Survey, Retired, 504 Rose Street, 228 Mining and Mineral Resources Building, Lexington, Kentucky, U.S.A.

Corresponding author: tbcjcc@gmail.com 


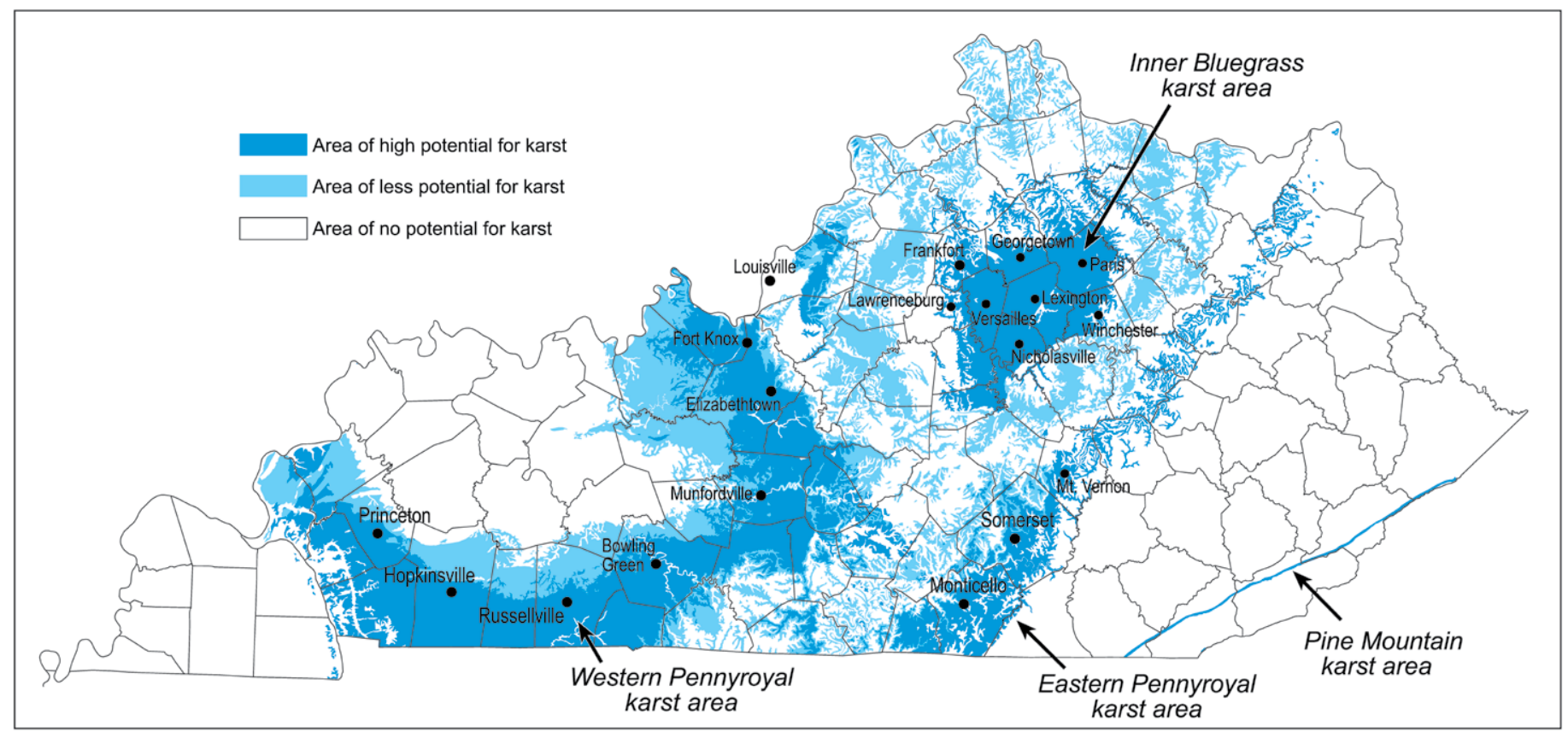

Figure 1. Kentucky karst occurrence map. Darker blue areas have a higher density of karst features.

Karst development is largest in the Western Pennyroyal area, which forms an arc from the Ohio River, near Fort Knox, south to the state's southern border, then west past Hopkinsville and north again back to the Ohio River (Fig. 1). The Western Pennyroyal is underlain by Mississippian (Lower Carboniferous) carbonates with an aggregated thickness up to $150 \mathrm{~m}$. Mississippian strata dip toward the Illinois basin and have hundreds of meters of Upper Mississippian and Pennsylvanian (Upper Carboniferous) deposits covering them in the center of the basin. Karst development is limited to the outcrop on the basin margins.

The Inner Bluegrass occurs in the central part of Kentucky. Lower to middle Ordovician limestones are draped over the Cincinnati Arch, a regional structural high. The Kentucky River has cut through the thick bedded, lower Ordovician, creating kilometers of near vertical cliffs flanking the river. Some of the deepest caves and vertical shafts in Kentucky are found in this region.

Geologically similar, the Eastern Pennyroyal and the Carter Caves area karst is developed in Mississippian limestones, which crop out along the margin of the Appalachian Basin and on the Carter Caves arch. The karst is aerially extensive and some of the longest caves in the state are found in the Eastern Pennyroyal. East and south of Louisville, the Scottville lowland is developed on Silurian and Devonian limestones and dolostone. Although the karst development is somewhat subdued, the area is known for frequent cover collapse.

Finally, there is the Pine Mountain area, created by the Hercynian orogeny, when compressive forces drove the deeply buried rocks to the surface along a fault that was partly parallel with the bedding. There are no communities in this area and cover collapse is seldom reported (Fig. 1).

\section{Previous Research}

There are six basic types of karst sinkholes (White, 1988, Waltham et al., 2005, Ford and Williams, 2007, Gutierrez, et al., 2008): solution (of bedrock), soluble bedrock collapse, (insoluble) cap rock collapse, cover collapse (also called dropout), suffusion, and buried. Of the six types of sinkholes, cover-collapse sinkholes are one of the most destructive, karst-related geologic hazards (Sowers, 1996). The process leading to the development of voids in unconsolidated material overlying karstic bedrock has been thought to be well understood for many years (White, 1988, White and White, 1992, White and White, 1999, Tharp, 2003). Soluble bedrock is riddled with small conduits (0.05 to $0.25 \mathrm{~m})$. The conduits in the bedrock eventually coalesce in a tributary pattern, confluent with a cave passage. A self-supporting roof of insoluble material (residual chert fragments, silt, loess, disaggregated sandstone, or fluvial sand and gravel) spans the growing void in the cover collapse (Currens et al., 2012).

Tharp (2003) has modeled cover collapse development and found that soil plasticity is a critical component. He also found plasticity of the cover in the immediate vicinity of the void decreases. Thus, the initiation of a cover collapse has been attributed to a loss of cohesion and surcharge loading from a wetting front (which results in a hydrostatic load), 


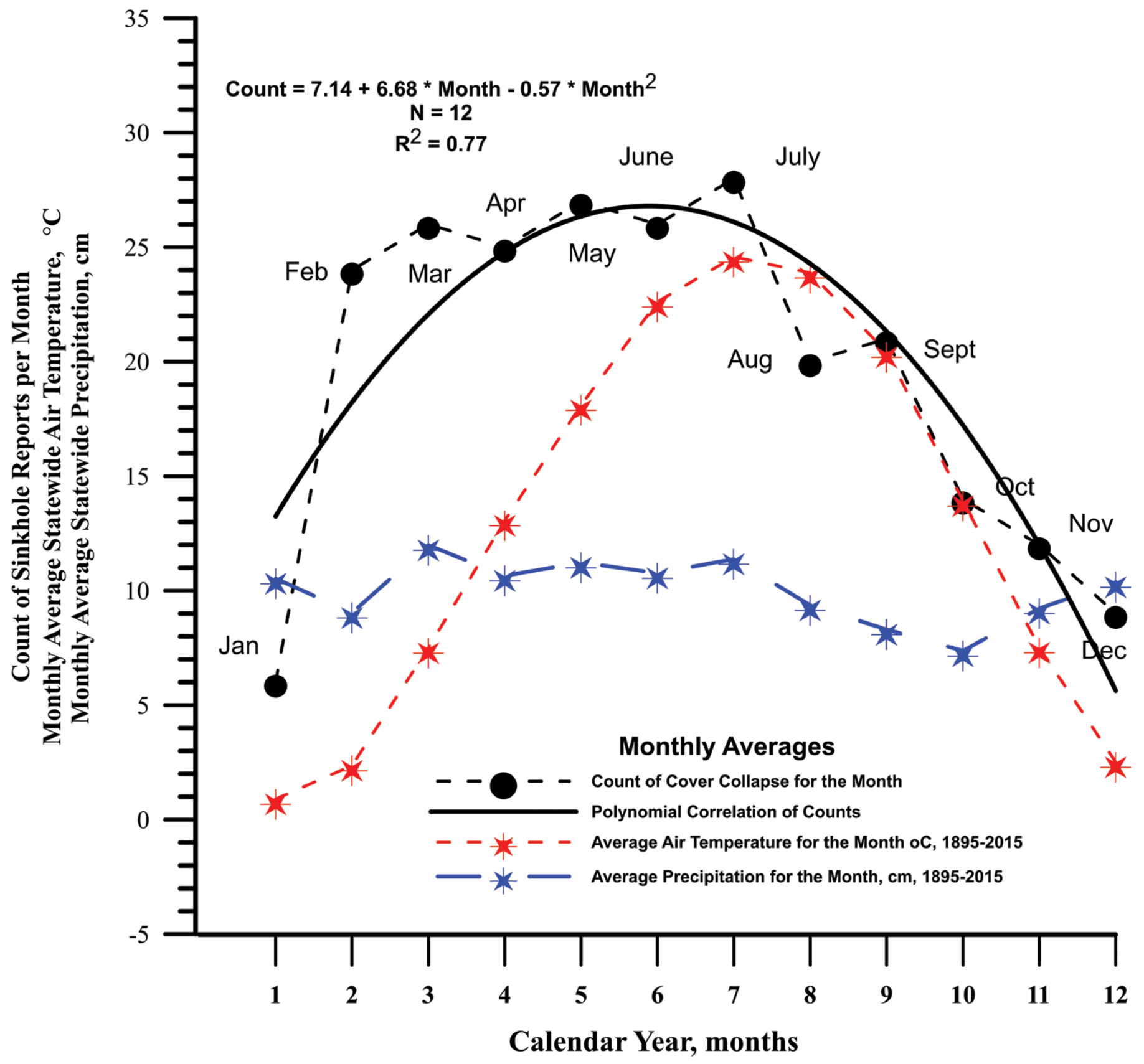

Figure 2. Relationship for the count of cover collapse per month to the average monthly state-wide precipitation and to air temperature.

and due to fracturing of the cover arch, loss of strength (Tharp, 1999). The spalling of layers of soil from the arch interior reduces the head gradient and may re-stabilize the arch until the next recharge event (Tharp, 1999).

Hyatt and Jacobs (1996) studied the geometry of 312 new sinkholes, resulting from a 500-year return-frequency flood along the Flint River in Georgia. The flooding occurred following $53 \mathrm{~cm}$ of rain in 19 hours from Tropical Storm Albert in July, 1994. Their findings noted that the new sinkholes had nearly circular outlines at the intersection with the surface and an apparent lack of influence by the regional jointing orientation. In the southeast United States, the elongation index (asymmetry ratio) ranges from 1.0 to 2.3 (Beck, 1991). Hyatt and Jacobs (1996) also noted closely-spaced clusters of new sinkholes in Georgia as a result of the riverine flooding. The relationship between older sinkholes and historic, documented cover collapse has also been studied by Hyatt, Wilkes and Jacobs (1999). They found that older sinkholes tended to be weakly clustered in groups, as opposed to randomly distributed. Their concluding remark, however, stated that nearest-neighbor analysis indicated that "the vast majority of new sinkholes have not clustered around old ones." Precipitation is thought to influence the timing and rate of cover collapse development (Tharp, 1999). In fields and woodlands, where recharge is slowed, and initially more evenly distributed over the surface by the canopy, grass land, or vegetative litter on the forest floor, the areal distribution of collapse is seemingly random. 
Development of analytical models to describe the dynamics and flux of heat and fluid (air, water, $\mathrm{CO}_{2}$ ) flow in the epikarst and the overlying cover have been evaluated (Covington, 2016). Permeability of the cover and its thickness relative to the epikarst are an important, limiting constraint on air flow between the karst subsurface and the surface. "If there is a thick, relatively [speaking], cover then this will shut down chimney-effect air flow within the fracture network below it" (Covington, 2016). By reciprocity then, if the cover has a sufficient number of interconnected macropores, air flow would be concentrated along those efficient routes, and the cover material adjacent to the macropores would experience more frequent wetting and drying cycles.

\section{Methods}

\section{Data Description}

The list of data gathered by KGS for each collapse was modified from the work of Wilson (Wilson and Shock, 1996). Parameters were omitted or added as thought relevant to the geology of Kentucky. When a call or email was received, often a decision had to be made as to whether the sinkhole report was credible enough to drive hundreds of miles to visit the collapse site. If the owner of the sinkhole could fill out the reporting form available online and attach digital photographs, the decision could be made much easier. The KGS online form includes the following fields:

Location:

Longitude and Latitude, dms

Longitude and Latitude, decimal

Elevation

$7 \frac{1}{2}$ minute, topographic quadrangle

County

Date: Year, season, month, day, hour

Of occurrence

Of report

Dimensions

Length, width, total depth
Azimuths of principal axes

Description of side-slope angle

General Shape

Sketch of cross-section and plan

Hydrologic Setting

Depth to water, if visible

Bedrock exposed

Depth to bedrock

General description of antecedent weather conditions

Soil name or type

\section{Calculated Parameters}

Length and width of the opening and the azimuth of the principal axes were measured at ground level. Unfortunately, the length and azimuth of the principal axis of the collapse were one parameter that was frequently omitted from the data on the form by property owners and other non-geologists filing a report. The diameter, elongation index (asymmetry ratio), and Riley Sphericity (proxy for circularity index) are calculated from the lengths of the long and short axis.

Circularity index can be conceptualized as the ratio of the areas of two circles, one of which has an imperfect outline, divided by that of a perfect circle (Montero and Bribiesca, 2009). The two area values are defined as having an equal diameter. Brinkmann et al., (2008) describe a circularity index they used for sinkholes in Hillsborough, Florida as comparing the diameter and area of a sinkhole with the area of a circle of the same diameter as the sinkhole. But no equation is provided and no source for the circularity is cited by Brinkmann et al.

Another circularity index is written as $C=P^{2} / 4 A$, where $P$ is the perimeter of the sinkhole and $A$ is the area of a circle (Montero and Bribiesca, 2009). The area of the sinkhole has to be measured independently to use either of the indices cited above. The majority of features described in this paper are frequently too new to be included in available photography and, further, are too small to be found on the same. An alternative method was needed. The Riley Sphericity (Folk, 1974) was used, where the $D_{c}$ is the diameter of the smallest circle circumscribing the collapse and $D_{i}$ is the diameter of the largest inscribed circle. By substituting the axis length for the diameters, $C=\sqrt{ }$ (short axis/long axis), that is used in this paper.

Although the depth is also an important parameter, the true depth of the cover collapse can seldom be measured because the bottom of void is typically obscured by the pile of soil and vegetation from the collapse of the arch. The overall depth of any cover collapse is constrained by relatively thin soils over the carbonate bedrock in the karst areas of Kentucky.

\section{Statistical Analysis}

Statistical analysis consisted of descriptive statistics, population testing with Student's T-tests, and GIS correlation. Multiple-variable analyses were also conducted to confirm results of the Student's $t$-tests. The analysis was conducted 
Table 1. Descriptive statistics for cover collapse reported in Kentucky.

\begin{tabular}{|c|c|c|c|c|c|}
\hline Parameters & Sample Size & Arithmetic Mean & $\begin{array}{l}\text { Standard Deviation } \\
\text { of Arithmetic Mean }\end{array}$ & Maximum & Geometric Mean \\
\hline Length of long axis (m) & 219 & 2.74 & 3.85 & 45.72 & 0.25 \\
\hline Length of short axis (m) & 219 & 1.85 & 2.73 & 32.31 & 0.08 \\
\hline Observable Depth (m) & 201 & 2.32 & 2.58 & 18.9 & 0.21 \\
\hline Diameter, $(L+W) / 2(\mathrm{~m})$ & 250 & 2.38 & 3.42 & 39.01 & 0.19 \\
\hline Asymmetry, $(L / W)$ & 219 & 1.96 & 2.11 & 10.6 & 0.17 \\
\hline Circularity, $\sqrt{(L \times S) / L^{2}}$ & 152 & 0.84 & 0.21 & 1.0 & -0.14 \\
\hline
\end{tabular}

with Excel spreadsheet, ArcGIS software and Statgraphics Centurion XVI software. Data were grouped based on the stratigraphy and the length, width, observable depth, diameter, elongation (asymmetry), and the circularity were tested for normal distribution and the equivalency of the mean. All of the data have a logarithmic distribution and all further analyses on these data were on transformed data (Table 1). Additional analyses were performed on the data set that had been characterized as an urban setting versus a rural setting.

\section{Weather Data}

Historical weather data from 1895 to 2015 were obtained from the University of Kentucky, College of Agriculture, AgWeatherCenter http://wwwagwx.ca.uky.edu/. Air temperature and precipitation depth was available as a statewide average for the month. An attempt was made to find data for soil temperature at any depth, dating at least to the turn of the 19th Century, but the soil-temperature data do not extend far enough into the past. I also contacted the Kentucky Climate Center at the Western Kentucky University in an attempt to locate detailed (daily or weekly) precipitation totals for an observation station nearest to the site of each cover collapse. Although detailed precipitation data were available for some sites, and a significant percentage of the data were compiled by Western Kentucky University, the amount of time needed to find and compile the entire subset of the data set exceeded the available resources. The KGS took an alternative approach and reviewed the data set again to find collapse events with a date accurate to the month of the collapse or better, resulting in 243 records. The records with a date accurate to the month were tallied irrespective of year and paired with average statewide precipitation for the calendar month.

\section{Results}

\section{Cover Collapse Dimensions}

Among the data sets tested by $t$-test (length, width, observable depth, diameter, elongation index [asymmetry ratio], circularity [Riley Sphericity], and an urban setting versus a rural setting) and multivariate analysis, there were only three statistically different pairs of data means. There is no statistical difference of the mean depth of cover collapse underlain by the Mississippian rocks when compared to the Ordovician carbonates (Table 2). The difference in depth between the collapses over Mississippian and Silurian-Devonian geology may be related to the overall thickness of the cover, and that, in turn, is possibly related to the thickness of the stratigraphic units. The Silurian-Devonian carbonates total 56 $\mathrm{m}$ in thickness, whereas the total Mississippian carbonate section ranges in thickness from $102 \mathrm{~m}$ to $262 \mathrm{~m}$, as much as a fivefold difference. There was a measurable difference in the depths between the Ordovician (2.4 m) and Siluri-

Table 2. Summary of results of student's t-test comparison of parameters grouped by geologic period of the underlying bedrock. All data were log transformed.

\begin{tabular}{|c|c|c|c|c|}
\hline Parameter & $\begin{array}{l}\text { Mississippian vs. } \\
\text { Ordovician }\end{array}$ & $\begin{array}{l}\text { Mississippian vs. } \\
\text { Silurian-Devonian }\end{array}$ & $\begin{array}{l}\text { Ordovician vs. } \\
\text { Silurian-Devonian }\end{array}$ & Urban vs. Rural \\
\hline Depth & $\begin{array}{l}f \text {-test: } \mathrm{M}=0 \\
t \text {-test: } \mathrm{M}=\mathrm{O}\end{array}$ & $\begin{array}{l}f \text {-test: } M=S-D \\
t \text {-test: } M \neq S-D\end{array}$ & $\begin{aligned} f \text {-test: } O & =S-D \\
t \text {-test: } O & =S-D\end{aligned}$ & $\begin{array}{l}f \text {-test: } U=\mathrm{R} \\
t \text {-test: } U=\mathrm{R}\end{array}$ \\
\hline Diameter & $\begin{array}{l}f \text {-test: } M \neq O \\
t \text {-test: } M \neq O\end{array}$ & $\begin{array}{l}f \text {-test: } M \neq S-D \\
t \text {-test: } M \neq S-D\end{array}$ & $\begin{array}{l}f \text {-test: } O \neq S-D \\
t \text {-test: } O \neq S-D\end{array}$ & $\begin{array}{l}f \text {-test: } U=R \\
t \text {-test: } U \neq R\end{array}$ \\
\hline Elongation (Asymmetry) & $\begin{array}{l}f \text {-test: } M \neq O \\
t \text {-test: } M \neq O\end{array}$ & $\begin{array}{l}f \text {-test: } M=S-D \\
t \text {-test: } M \neq S-D\end{array}$ & $\begin{array}{l}f \text {-test: } O=S-D \\
t \text {-test: } O \neq S-D\end{array}$ & $\begin{array}{l}f \text {-test: } U \neq \mathrm{R} \\
t \text {-test: } U \neq \mathrm{R}\end{array}$ \\
\hline $\begin{array}{l}\text { Riley Sphericity } \\
\text { (Circularity) }\end{array}$ & $\begin{array}{l}f \text {-test: } M \neq 0 \\
t \text {-test: } M \neq 0\end{array}$ & $\begin{array}{l}f \text {-test: } M \neq S-D \\
t \text {-test: } M \neq S-D\end{array}$ & $\begin{array}{l}f \text {-test: } O=S-D \\
t \text {-test: } O \neq S-D\end{array}$ & $\begin{array}{l}f \text {-test: } U=\mathrm{R} \\
t \text {-test: } U \neq \mathrm{R}\end{array}$ \\
\hline
\end{tabular}

Note: All comparisons are to a $95 \%(\alpha=0.05)$ confidence interval. $t$-test is the student's $t$-test of the equivalency of the means. $f$-test tests the equivalency of the variance. The $\neq$ symbol indicates the comparison of the two samples is statistically different. The = symbol indicates the two sample sets are not statistically different. M is Mississippian, $\mathrm{O}$ is Ordovician, and S-D is Silurian-Devonian. $\mathrm{U}$ is urban and $\mathrm{R}$ is rural. 
an-Devonian $(1.6 \mathrm{~m})$ cover-collapse, but this is not statistically significant. The means for elongation index (asymmetry ratio) were not the same for Mississippian versus the Silurian-Devonian or the Ordovician versus the Silurian-Devonian, although the variance was equal. The only other parameter that was found to have similar variance was the circularity (Riley Sphericity) for the Ordovician versus the Silurian-Devonian, but the means of this data set were not equal.

The relationship of recent cover collapses, which were free of anthropomorphic-generated debris, to the anecdotal oral history to the contrary (e.g., there is trash in every sinkhole) was surprising. The presence of buried trash re-exposed by recent collapse strongly indicates the feature had been known for some time (years) before being filled. If the sinkhole was filled with clean rock and soil, unless there is other evidence it is reactivated, it could be assumed to be new. If this information is coupled with the findings of Hyatt (Hyatt, Wilkes, and Jacobs, 1999), which suggests that new cover collapse does not preferentially form near older sinkholes, then the relationship of new cover collapse to larger, mapped sinkholes becomes more difficult to resolve.

\section{Weather}

Anthropomorphic accentuation of runoff from impermeable surfaces, such as parking lots, is a common cause of collapse in urbanized areas. There are case histories in this database that involve seemingly inconsequential water sources, such as onsite sewage disposal, drips from a leaking gutter, downspouts discharging next to a foundation, and even air conditioner condensate.

The average monthly precipitation data for Kentucky from 1895 through 2015 was plotted against the number of sinkholes per month and fitted with a linear regression. The correlation coefficient was 0.56 at $\alpha=0.05$. The comparatively weak correlation is thought to be produced by the average precipitation being too generalized. A polynomial regres-

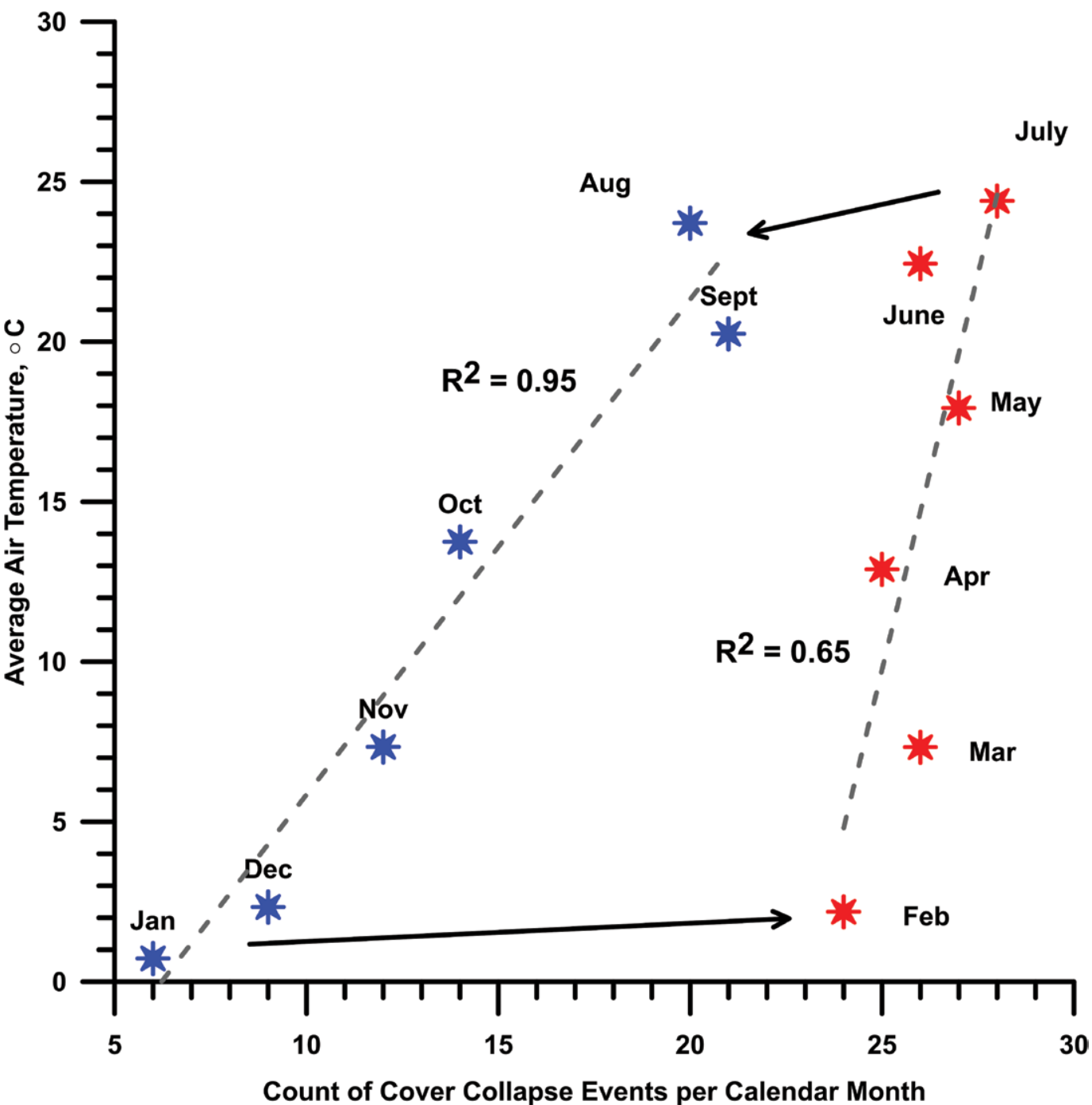

Figure 3. Trend in the tally of collapse per month compared to the monthly average air temperature. sion drawn through all 12 monthly counts, versus precipitation, shows a modest improvement in predicting the counts over the linear regression $\left(r^{2}=\right.$ 0.77, $\alpha=0.05$ ) (Fig. 2). Because of association of concentrated runoff, the wetter months have been thought to have more frequent incidents of cover collapse.

It was also observed that the average monthly temperature and the monthly total of collapse events plotted closer to parallel than had other paired data examined during this study. The data pairs were initially plotted as a single data set with twelve pairs of observations $\left(r^{2}=0.50\right)$. Then, the data were partitioned into two sub-sets, which revealed a warming period (February through July) and a cooling period (August continuing into January) (Fig. 3). The correlation coefficient of the cooling subset is strongly improved $\left(r^{2}=0.95\right)$ over the 12-month data set, 


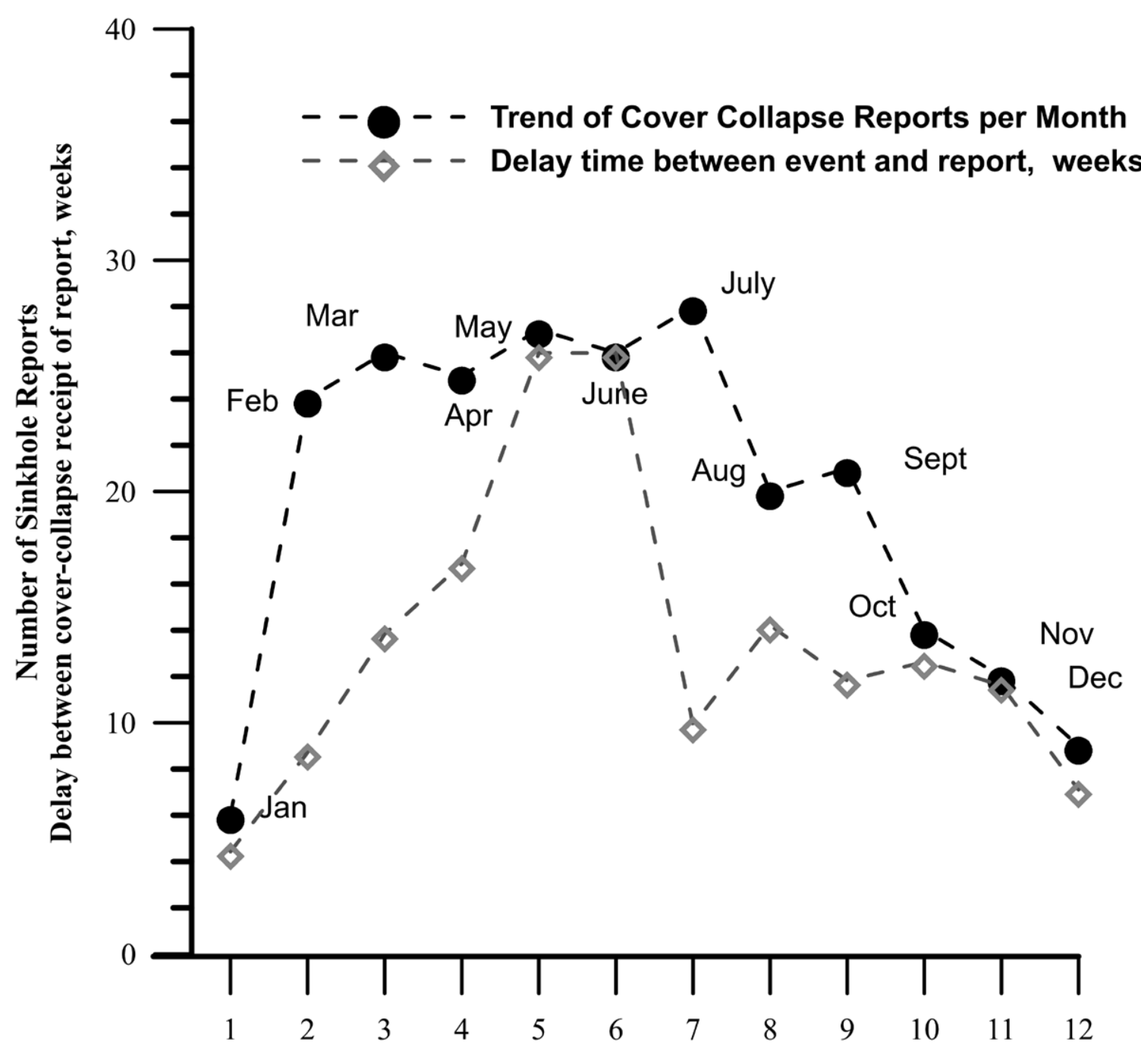

Calendar Year, months linear regression, whereas the warming trend sub set also shows a noticeable improvement $\left(r^{2}\right.$ $=0.64)$. These statistics are for the total counts per month for all years, derived from no fewer than six and as many as 28 observations per month. By posting the data in subsets from February to July and August to January, the relationship of the temperature data to the collapse counts became clearer.

The comparatively few reports of collapse in December and January have prompted some criticism (William Andrews,

Figure 4. Delay between the estimated date of collapse events and the date of the report, by month.

personal communication, 2016). For example, July has six times as many collapses as February. One hypothesis to explain this was that the ground surface could be frozen from November to February. A cold front that results in a short, but especially cold period (temperatures near $-10^{\circ} \mathrm{C}$ ) may briefly freeze the soil in the shallow subsurface. When the temperature begins to warm, frozen soil inhibits infiltration of rain or snow melt (Seyfried and Murdock, 1997). Frozen soil would also add mechanical strength to an incipient cover collapse, postponing failure of the arch. Soil frozen more than $5 \mathrm{~cm}$ deep is very uncommon in Kentucky.

Another explanation (Drew Andrews, personal communication, 2016) is that there are fewer people actively outside during the winter to find and report a cover collapse. To address this possibility, the data set was reviewed yet again to include 164 data pairs with dates precise enough to determine the period between the event and the report to the nearest week. The graph clearly shows that the longest delays between the event and the report are, except for July, in the late spring and early summer of the calendar year (Fig. 4). The July data are skewed by a physical cluster of cover collapses, which had a similar estimated date of occurrence, a uniform date of the report, and were smaller in diameter than average. All other conditions being equal, the winter months have the shortest delay times between event and report.

In contrast, leafed-out summer foliage hides many of the cover collapse openings. Accounts of farmers driving a tractor across a field of tall crops, hay, or weeds, and driving into an obscured cover collapse that wasn't there the last time the field was harvested, are common. The same cover collapse openings would be relatively visible in the winter. The trend in the delay times strongly suggests that human observation plays a minor role in biasing the cover collapse winter data. 


\section{Air Flow}

The warming and cooling trends shown in Figure 4 suggest that above-ground temperatures are either directly involved in the cover collapse mechanism or they are promoting some other process that affects the coherency of the soil void. If air temperature is a direct cause, the air from the surface, driven by the relative density, would flow into the ground during cold weather via a large range of opening sizes (Palmer, 2007). During warm weather the flow direction reverses. The completion of an air flow circuit could explain the development of the soil arch at a specific location. Relatively warm air flowing out in winter would be laden with moisture and would be ineffective at drying the arch materials. Those less common configurations in winter where cold air is flowing into the ground would adsorb a significant mass of moisture as it warms from contact with the soil. The seasonal fall and winter desiccation and springtime wetting of the arch earth materials would eventually trigger a cover collapse.

\section{Conclusions}

The hypothesis developed from this analysis is that the frequency (counts) of cover collapse events per month is related to the air temperature. Soil water infiltrating during the early spring rainy season, followed by air flow drying in the fall and winter, would cause desiccation cracking and spalling of the soil arch. A possible sequence of events leading to a cover collapse are:

1. Water flowing through soil macropores reaches the limestone and enlarges fractures into conduits, enough to allow turbulent flow. At this size of conduit development, discharge may not be great enough to always fill the conduit with water and some air space will become a more common condition. Eventually, all of the water will drain to a lower elevation, and the now air-filled conduit will remain connected to the surface through soil macropores created by recharge.

2. Once the flow path for air becomes established, the spalling process will become more frequent and effective. Each wetting cycle expands the soil void by putting hydraulic pressure on the compressed zone of earth material, forming the most interior band of the arch. If the hydraulic pressure is too great, the interior part of the arch will fail.

3. Each drying cycle creates cracking caused by clay in the wetted ceiling of the soil void, shrinking as the moisture is removed by airflow. Cool, dry air in the fall, its flow direction controlled by air density and the humidity by dry air from the surface, would promote the shrinking of the earth material forming the void ceiling.

4. The arch thins as the void ceiling approaches the surface. The arch becomes too thin for the internal shear strength of the remaining cover to support its own weight and it fails.

The implications of this hypothesis may go well beyond the phenomena of cover collapse. For example, it could have profound implications for the accumulation of radon in basements and crawl spaces of buildings.

Future researchers should attempt to locate and instrument a soil void well before it collapses. The research plan would begin with locating as many soil voids as possible that are at various depths. A protocol to install a variety of instrumentation would be needed to test the hypothesis. The equipment needed would include: an access port for a downhole camera, a small-diameter well for collecting water samples, if appropriate, access for two pressure transducers, a temperature sensor, and a relative humidity probe.

\section{Acknowledgements}

The support of the Kentucky Geological Survey at the University of Kentucky is gratefully acknowledged. Dr. Stuart A. Foster, State Climatologist for Kentucky, Kentucky Climate Center at Western Kentucky University researched the site-specific precipitation data. Thanks to Mr. Chuck Taylor for his advice and encouragement.

\section{References Cited}

Beck, B.F., 1991, On calculating the risk of sinkhole collapse, in Kasting, E.H., and Kasting, K.M., eds., Appalachian Karst, proceedings of the Appalachian Karst Symposium, Radford, Va., March 23-26, 1991: National Speleological Society, Huntsville, Ala., p. $231-236$.

Brinkmann, R., Parise, M., and Dye, D., 2008, Sinkhole distribution in a rapidly developing urban environment: Hillsborough County, Tampa Bay area, Florida; Engineering Geology, v 99, p 169-184. https://doi.org/10.1016/j.enggeo.2007.11.020.

Cecil, M.C., 2015, Population and land use in Kentucky karst regions: independent study final report, Departments of Earth and Environmental Studies, Department of Geography, and Kentucky Geological Survey, 15 p.

Covington, M.D., 2016, The importance of advection for $\mathrm{CO}_{2}$ dynamics in the karst critical zone: an approach from dimensional analysis in Feinberg, J. M., Gao, Yungli, and Alexander, E.C., Jr., eds., Caves and Karst Across Time, Special Paper 519: Boulder, Colo., Geological Society of America, p. 113--127.

Currens, J.C., 2002, Kentucky is karst country! What you should know about sinkholes and springs: Kentucky Geological Survey, Ser. 12, IC 4,29 p.

Currens, J.C., 2012, Cover-collapse sinkholes in Kentucky, USA: geographic and temporal distribution: carbonates and evaporites, v. 27, p. 137142. https://doi.org/10.1007/s13146-012-0097-2.

Currens, J.C., Paylor, R.L., Beck, G.E. and Davidson, B., 2012, A method to determine cover-collapse frequency in the western Pennyroyal karst of Kentucky: Journal of Cave and Karst Studies, v. 74, no.3, p. 292-299. https://doi.org/10.4311/2011ES0247. 
Dinger, J.S., Zourarakis, D.P., and Currens, J.C., 2007, Spectral enhancement and automated extraction of potential sinkhole features from NAIP imagery-Initial Investigations: Journal of Environmental Informatics, v. 10, no. 1, p. 22-29. https://doi.org/10.3808/jei.200700096.

Ford, D.C., and Williams P.W., 2007, Karst hydrogeology and geomorphology: Chichester, West Sussex, U.K., John Wiley \& Sons, Ltd, 562 p.

Folk, R.L., 1974, Petrology of sedimentary rocks: Austin, University of Texas, Hemphill Publishing Co., 182 p.

Gutierrez, F., Guerrero, J. Lucha, P., 2008, A genetic classification of sinkholes illustrated from evaporite paleokarst in Spain: Environmental Geology, v. 53, p. 993-1006. https://doi.org/10.1007/s00254-007-0727-5.

Hyatt, J.A., and Jacobs, P.M., 1996, Distribution and morphology of sinkholes triggered by flooding following Tropical Storm Alberto at Albany, Georgia, USA: Geomorphology, v. 17, p. 303-316. https://doi.org/10.1016/0169-555X(96)00014-1.

Hyatt, J.A., Wilkes, H.P., and Jacobs, P.M., 1999, Spatial relationships between new and old sinkholes in covered karst, Albany, Georgia, USA, in Beck, B.F., Pettit, and Herring, J.G., eds., Hydrogeology and Engineering Geology of Sinkholes and Karst: Rotterdam, Netherlands, Balkema, p. 37-44.

Kambesis, P., Crawford, N., Croft, L.A., Moore, R., and Pfaff, R., 2003, Dishman Lane collapse, Bowling Green, Kentucky, in Sinkholes and the Engineering and Environmental Impacts of Karst, Beck, B.F., ed.: Proceedings of the Ninth Multidisciplinary Conference, Geotechnical Publication No. 122, American Society of Civil Engineers, National Groundwater Association, GEO Institute, and P.E. LaMoreaux \& Associates, Inc., p. 404-737.

Montero, R.S., and Bribiesca, E., 2009, State of the art of compactness and circularity: International Mathematical Forum, 4, no. 27, p. 13051335.

Palmer, A.N., 2007, Cave Geology: Cave Books, Cave Research Foundation, 454 p.

Seal, L. D., 2005, Creation, analysis and evaluation of remote sensing sinkhole databases for Pinellas County, Florida [M.S. Thesis]: Tampa, University of South Florida, Department of Geology, 55 p.

Seyfried, M.S., and Murdock, M.D., 1997, Use of air permeability to estimate infiltrability of frozen soil: Journal of Hydrology, v. 202, p. 95-107. https://doi.org/10.1016/S0022-1694(97)00061-9.

Sowers, G.F., 1996, Building on sinkholes: New York, American Society of Civil Engineers, 202 p. https://doi.org/10.1061/9780784401767.

Tharp, T. M., 1999, Mechanics of formation of sinkholes: Engineering Geology, v.52, p.23-33. https://doi.org/10.1016/S0013-7952(98)00051-9.

Tharp, T. M., (2003). Sinkhole formation and soil plasticity in Sinkholes and the Engineering and Environmental Impacts of Karst, Beck, B. F., ed.: Proceedings of the Ninth Multidisciplinary Conference, Geotechnical Publication No. 122, American Society of Civil Engineers, National Groundwater Association, GEO Institute, and P.E. LaMoreaux \& Associates, Inc., p. 110-123.

Waltham, T., Bell, F., and Culshaw, M., 2005, Sinkholes and subsidence: karst and cavernous rocks in engineering and construction: New York, Springer-Praxis Books in Geophysical Sciences, 382 p.

White, W.B., 1988, Geomorphology and hydrology of karst terrains: New York, Oxford University Press, p. 387-402.

White, W.B., 1999, Karst hydrology: recent developments and open questions: Proceedings of the $7^{\text {th }}$ Multidisciplinary Conference on Sinkholes and the Environmental Impacts of Karst: Rotterdam, Netherlands, Balkema, p. 3-21.

White, W.B., and White, E.L., 1992, Sinkholes and sinkhole collapses, in Majundar, S.K., Forbes, E.W., and Schmalz, R.F., Eds., Natural and technological disasters: Effects and preventative measures: The Pennsylvania Academy of Science, p. 280-293.

Wilson, W.L., and Shock, E.J., (1996). New sinkhole data spreadsheet manual: Winter Springs, Fla., Subsurface Evaluations Inc., version 1.1, 34 $\mathrm{p}$, appendices, 3.5 in diskette. 